\title{
The Logic of Another Time and Place: An Argument Relating to the History of Work Time ${ }^{1}$
}

\author{
JON HENNING
}

\begin{abstract}
Part review, part sequel, this essay critiques the neoliberal-tinged argument presented by Huberman and Minns against the use of government policy in the "New World" to assist the shortening of working hours. It dissects the methodology used to support their argument and accesses New Zealand's historical experience to challenge their findings and conclusions.
\end{abstract}

\section{Introduction}

Michael Huberman and Chris Minns's paper, “The Times they are not Changin': Days and Hours of Work in Old and New Worlds, 1870-2000," has been cited in a number of articles on the subject of worktime. ${ }^{2}$ It has also been praised by Raymond Markey in the authoritative journal, Labour History, as "an important example of how the comparative method may correct common perceptions based on introspective national perspectives." ${ }^{3}$ In fact, the paper has significant flaws. While the main data sets usefully show the relative movement of work time reduction for full-time industrial workers in various countries, the associated analysis is questionable and the suggested conclusions contentious. This article considers the main points made by Huberman and Minns in relation to annualised work hours, and provides information relating to work time in New Zealand to highlight difficulties with the paper. Their sole reference to New Zealand is in a footnote and even so is incorrect. ${ }^{4}$

Huberman and Minns consolidate hours of work data into Old World and New World regional categories, dating from 1870 to 2000 . The focus of their analysis is to show three things: first, a distinction between the Old World and the New World with respect to the reduction in work hours; second, that the trends of the second half of the twentieth century were already evident in the period 1870 to 1913 and that these periods are linked; and third, the significance or otherwise of some measurable variables. These variables are labour power, inequality, and work ethic. From their analysis, they draw three conclusions. First, that workers in the Old World had more days off and experienced a faster reduction in work hours per week, and that contributing to these trends were matters of more labour power in the Old World and more inequality in the New World. Second, the predisposition of New World workers "to give more labor time" is conceived as a likely "home grown phenomenon, rooted in location and not in peoples." Third, Huberman and Minns add to this enigmatic speculation that "if history does matter, then policy proposals to transform the Old World into the New, or vice versa, by changing tax schedules or consumption patterns in one direction or another need to be reconsidered." They are generally sceptical that policies, possibly successful in the Old World, would work in the New World. ${ }^{5}$ They discourage dynamic New World economies from adopting European ideas on reducing worktime. An important question for this current paper is whether the evidence really indicates that progressive European ideas on reducing hours should not be trialled or adopted by others.

To approximate the New World perspective, Huberman and Minns select only three countries: the United States, Canada and Australia. The selection is not only too few, but also has a strong Anglo-colonial bias. Moreover, the North American pattern, and particularly that of the largest factor, the United States, varies significantly from the pattern revealed in the Australian data.

Journal of New Zealand Studies NS28 (2019), 69-83 https://doi.org/10.26686/jnzs.v0iNS28.5421 
A very simple comparison of the raw data on annual hours of work, first for Australia and the Old World and then for the United States and the Old World, underscores entirely different experiences. Australian hours of work were consistently well below the Old World average to 1913. The gap subsequently closed from 1929 to 1973 and Europeans worked increasingly fewer hours from 1980. By contrast, the Americans initially worked slightly fewer hours and then substantially more hours than the mean for the Old World from 1870 to 1929. A sudden and dramatic reduction in American hours between 1929 and 1938 dropped them below European hours. The new gap then progressively narrowed, until Old World hours returned to being lower and then substantially lower from $1973 .^{6}$

The periodisation used by Huberman and Minns is also faulty. They argue strongly that the New World and Old World have been on distinct and different regional trajectories from 1870 until at least 2000, with the exception of an aberrant period from 1913 to 1950. The argument does not match the data.

Looking simply at the Australian data, there is a reduction in annual hours of work for each successive date of measurement from 1870 to 2000. Looking specifically at the rate of change in this data, the annual hours of work reduced at a rate of about 150 hours each decade to 1913, then reduced by only 28 hours in the period from 1913 to 1929 , and thereafter reduced at rates of between about 75 and 110 hours each decade until 1973. The rate of change then slumped to reductions of only about 10 to 20 hours each decade for the period to 2000 . For the same data series, the United States experienced a much more modest reduction in annual hours from 1870 to 1913 of between about 40 to 60 hours over each successive decade. From 1913 to 1938 , however, annual hours of work reduced extraordinarily by over 1100 hours. Annual hours of work then increased by a substantial 252 hours over the period to 1950, and by 25 hours over the next decade, to 1960, before again falling by about 90 hours in 1973 and again in 1980 . The annual hours worked in 1990 were 13 less than the previous figure. Annual hours of work increased again by 38 from 1990 to 2000. To compare, the data generally for the Old World show that the annual hours of work reduced erratically by between 79 hours and 125 hours each decade from 1870 to 1913. Like the United States, annual hours of work reduced substantially - by 551 - to 1929, but then more modestly-by 95 hours - to 1938. Annual hours of work increased by 27 from 1938 to 1950, but thereafter reduced by between 70 and 197 hours for each decade from 1960 to $2000 .^{7}$

In relation to the finding by Huberman and Minns that the Old World progressed faster than the New World in reducing hours in the periods 1870 to 1913 and after 1950, the data show that, despite already having exceptionally low working hours, the annual working hours for Australian workers reduced by 578 for the first period. By contrast, the hours reduced in the Old World by 417 and by only 196 in the United States. The data also indicate complexity in the trends from the First World War to the period immediately following the Second World War and at the very least two separate trends after this post Second World War period, with the latter commencing somewhere around the 1980s. ${ }^{8}$

Huberman and Minns offer no clear explanation for the 1870 start date of their analysis. They refer at several points to prior matters, including brief discussion about "traditional religious and social calendars" and the Puritans of the seventeenth century and their work values. ${ }^{9}$ There is also comment on the "deep historical roots" of the relation between inequality and hours of work and to the reassertion of "ages old patterns." 10 None of this, however, explains why the specific period from 1870 to 1913 was "a prelude to developments after 1950."11 
Huberman and Minns not only seek to explain different regional rates of working hour reduction, but also to explain why New World workers worked longer hours; this despite the fact that their main data sets show that New World workers generally worked shorter hours than their Old World counterparts. They seek to show that the shorter hours are an illusion, thus validating various causes and justifications for longer hours in the New World. Their argument is that New World workers worked longer hours than they should have if their wages relative to Old World wages are taken into account.

To look first at the attempt by Huberman and Minns to explain why, historically, longer hours have been worked in the New World, the causes principally considered are wage inequality, labour power and work ethic. Huberman and Minns state the Old World had less inequality than the New World and that "inequality in the New World led to longer hours before 1900."12 They also cite findings specifically attributing the trend in the United States towards the end of the twentieth century of longer hours to rising inequality. Underpinning the findings is the "incentive-based argument that those who work longer move up in the wage distribution and the gains for doing so are greater the more unequal the wage distribution." They state that the pattern of the earlier period "was mimicked" in the latter. ${ }^{13}$

In testing the impact of inequality, Huberman and Minns look particularly at wage inequality measured by the difference between minimum and maximum wages at the enterprise level. There is a struggle for useful data, and they find only limited evidence to support the link between wage inequality and longer hours in the New World. They state, however, that "as expected, in the New World rising dispersion led to longer hours, a result that is stronger when Australia is omitted." Huberman and Minns state nevertheless that their results "point to a more general explanation of the effect of inequality on hours" that is "closer in spirit" to a "model of social emulation." 14 Elsewhere, they relate the model to "the drive to emulate some better off reference group" that provides the basis for "a deeper work ethic." 15 The point is consolidated by reference to other economic historians. From this literature, they note: "In the Old World, labor power came to represent the voice of the average worker and legislation to reduce the work day had the effect of narrowing wage gaps. In contrast, in fluid and dynamic economies like the US in the late nineteenth century inequality was endemic." They say that their results are consistent with the view that "new participants entered relocated, changed occupations, and took risks to capture the opportunities before them."

Labour power is regarded as an important influence on hours particularly in relation to progress in the Old World. Huberman and Minns say that the Old World had more labour power and they "find that [this] labour power, proxied by the percentage of voters in the male population, reduced working hours in Europe before 1913." "The proxy is used because union density was very low and progress "was tied to the numbers who voted." 18 In turn, the wider the suffrage the more likely labour friendly legislation, this being the key to shorter hours. Old World labour power before 1913 was expressed by general election votes because unions were weak; for the modern period it was embodied by strong unions able to influence the state directly. ${ }^{19}$

Why then did labour power not have the same impact in the New World? New World suffrage rates were already ahead of the Old World in 1870. To help explain, Huberman and Minns note the fragmented political structure of the New World countries and that regulation developed at the state or provincial level, hindering the development of national standards. ${ }^{20}$ One objection to this view is that Australia was not a federal entity until 1901. The reality of the Old World was also one of considerable fragmentation, whether considered through the prism of federalism or as a collection of independent states. Further, it is not necessarily true that federal

Journal of New Zealand Studies NS28 (2019), 69-83 https://doi.org/10.26686/jnzs.v0iNS28.5421 
structures will tend to slow progressive legislation, nationally or otherwise. It is entirely possible that such structures as much allow a subnational outlet for legislation that is otherwise impossible at the level of the national entity because the overall political balance is against enactment. ${ }^{21}$ Defensively, Huberman and Minns add that "Anyway [emphasis added], at the local level voters' interests . . . lay elsewhere. ... Strong labour mobility was the norm in the New World. It was the marginal worker that determined outcomes in the labor market and this meant short-job attachments, long hours of work and corresponding wage premiums."22

In explaining trends after the Second World War, Huberman and Minns do not rely on the argument of greater labour power or union influence in the Old World relative to the New World but on different union interests. In the Old World, unions sought shorter hours, but in the New World they preferred "to stock up on consumer goods." ${ }^{23}$ In relation to the interwar years and the development of the particular factor of paid leave, Old World governments were responding to increasing labour power as well as pressure from the ILO and the example of the Soviet Union and eastern European countries. In North America, the explanation is not about what governments did or did not do but that employers had progressed paid holidays in the 1920 s to diminish the attraction of unions and then removed these in the $1930 \mathrm{~s} .{ }^{24}$ Huberman and Minns's data on holidays for the first half of the twentieth century are limited to figures only for 1900, 1938 and 1950. If anything, they contradict the explanation. Holidays in the United States and the Old World increased by almost the same number from 1900 to 1938. The change also constituted a much greater percentage increase in the United States because of its very low number of holidays in 1900. After the Second World War, the Europeans continued on the path of legislative support for increased holidays. This did not occur in the New World. ${ }^{25}$

Huberman and Minns add the issue of "the culture gap" to their explanation of longer hours in the New World. They note that "the literature on deep-factors that explain why New World workers gave - and continue to give-long hours independent of their levels of income is crowded, but religious affiliation and the work ethic, . . . legal origins of contract law, . . . selective immigration, and climate are usually at the top of the list." ${ }^{26}$ Limited by the data available, Huberman and Minns test for only two of these factors, religious affiliation and work ethic. In reality, their causal factor is only work ethic, this being indicated by the measurement of religious affiliation and schooling. The first measurement is confined to the extent to which immigrants were Protestant. Huberman and Minns note the commonplace understanding of Protestant "ascetic injunctions" and the embedding of these injunctions in the New World. In particular, they refer to the impact of the Puritans on the elimination of saints' days. The proportion of Protestants in the New World in 1870 was 62\%; in the Old World, 52\%. The second measurement is the percentage of the regional populations receiving primary schooling. Huberman and Minns state that this reflects the rate of transmission of cultural values, such as work ethic, and also, from "an economic perspective," the expression of a commitment to market work "by individuals who have increased their earning power through education." Schooling levels were 50\% higher in the New World in 1870 and $40 \%$ higher in $1913 .{ }^{27}$ There is a strong element of traditional religious caricature and nominalism behind these particular measures of work ethic.

To come back to the starting point of Huberman and Minns's general consideration of cause, they seek to test whether reasons given for longer hours in the New World in recent times were also reasons for longer hours in the period 1870 to 1913 . This starting point is, in itself, problematic. 
Huberman and Minns claim that workers in the New World worked longer hours than Old World workers. The reasoning for this is twofold. First, wages are the most important of the issues determining changes in worktime. ${ }^{28}$ Second, they calculate that the New World workers tended to work longer than Old World workers if their relative incomes are taken into account. To be clear, in 1870, New World workers worked only about 10 percent less than Old World workers when their income was about a third higher. The argument is that they should have worked much less. Generally, Huberman and Minns calculate from such differences for 1900 that "a 10-percent increase in the hourly wage led to a shorter workweek of 1.2 percent." 29 By controlling for wages, the question which appears to need an answer from the raw worktime data is reversed. Instead of requiring an explanation for Old World workers tending to work longer hours, the question posed by Huberman and Minns is why did the New World workers tend to work longer than would have been expected if workers in the Old World and New World had been paid similar wages?

It is certainly true that as real wages have risen, hours of work have tended to decline. Huberman and Minns suggest an average ratio of approximately 10:1. There are factors, however, that suggest that this ratio cannot be applied as a uniform expectation for all countries or for regional groupings of countries. Wages are not the sole determinant of hours of work, and there may be factors yet to be identified. And while wages are generally regarded as the most important factor, there is very little clarity otherwise about how important it is relative to other factors. Further, it is more than conceivable that the ratio increases for the countriesand regions-with the shortest work hours. Progress is likely to slow with the approach or achievement of the ideals of the eight-hour day and then the five-day week, in the first place for the occupational groups most advantaged or most able to leverage such hours in bargaining, and then generally, and even more slowly, for other elements of the labour force that face greater resistance to reduced hours. Moreover, workers already ahead in terms of reduced hours are likely to be relatively less motivated to press for further reduction because, borrowing from the Huberman and Minns phraseology, they lack the incentive of emulation. Convergence and diminishing returns appear likely to be factors in a significant and increasing ratio between rising wages and falling hours.

In addition, Huberman and Minns make selective use of "a different optic." ${ }^{30}$ In other words, what would relationships between wages and hours look like without esoteric statistical computations? Huberman and Minns suggest that employers offered longer hours because of capital intensity. This is barking up the wrong tree. Regardless of whether workers worked longer hours than they should have, the hours actually worked were shorter in the New World until 1973. Employers did not provide longer hours. An argument that employers opposed shorter hours because of greater capital investments would make more sense. Equally simply, the reality of better paid workers working shorter hours does not reflect or need an explanation of a greater work ethic. The causal arguments look rather like a house of cards.

Huberman and Minns say that their "aim is not to write a history of worktimes." 31 Given the catholic breadth of the discipline, they have intruded into the realm of historical discussion, intentions notwithstanding. New research into the early history of worktime in New Zealand, supplemented by reference to official data published in New Zealand and sketches which extend the view through the twentieth century and into the early twenty-first century, provide interesting checks and contrasts to their paper. ${ }^{32}$

First, some qualifications and comments on the available New Zealand research and data. The additional consideration of New Zealand does nothing to expand upon Huberman and Minns's 
New World construct. It was a British colony and indeed so closely tied to the Australian colonies that it participated in talks dating from the 1860s over prospects of being part of a greater Australia. Further, there are no statistical data sets available in the new research relating to the nineteenth century. The research is based on letters, newspaper reports and government publications such as special commission and departmental reports, parliamentary debates, and industrial awards. ${ }^{33}$

New Zealand statistical data of various degrees of usefulness are available from 1909. ${ }^{34}$ Like the data presented by Huberman and Minns, the New Zealand data are based on urban workers. But it is only published on the basis of weekly hours. This is not a serious impediment for the purposes of comparison as the principle concern is with rates of change, not specific aggregations of work hours, and reasonable assumptions can be made in relation to statutory increases in annual holidays.

In terms of degrees of usefulness, the initial New Zealand statistics are based on the awards that followed from the enactment of the Industrial Conciliation and Arbitration Act 1894. The information therefore concerns trends based on standard hours and not actual hours. Regardless, the direction of travel for both is likely linked. Unions and their supporters sought reductions in standard hours for two reasons: they wanted to work less hours; and if they did work over standard hours, they wanted to be paid more. Awards increased the reward for extra work and acted on employers as a disincentive to require overtime. Further, awards, as enforceable documents, put unions in a stronger position to press for limitations on overtime and on unpaid work. The coverage of awards also grew over time. The effect of award provisions in decreasing hours of work was therefore amplified.

Average actual hours were first recorded in the New Zealand Official Year-Book in 1958 for the previous year, initially for male workers only but by the 1960s for all workers. Because the Year-Book provides overlapping series for the years of transition from awards to actual hours for all workers it is possible to develop a picture of percentage changes in New Zealand hours of work that relate directly to the years selected by Huberman and Minns. The development of actual hours series appears to advance the monitoring of changes in hours of work.

The capture of unpaid work may have become more problematic, however. While paid work is formally recorded in writing on an ongoing basis and thus easy to accurately survey, unpaid work is generally not. The perception is that unpaid work has expanded as an issue over the last two or more decades. ${ }^{35}$ The expansion is linked to the development of technology that enables work away from the work site and - clearly in New Zealand - to deunionisation, which has enabled employers to impose higher thresholds of work on workers. The workers perhaps most affected include those in supervisory roles and more autonomous workers. The issue is important if the level of unpaid work is changing at a rate that differs from the trends for standard and overtime work. The modern picture has also become more complicated with the return to a higher incidence of precarious work. This paper is essentially an extended critique of the Huberman and Minns paper, which at its heart argues that there is a connection between the period from 1870 to the beginning of the First World War and the period from 1950 to 2000. The period after 2000 may therefore be regarded as out of scope. Some parting remarks are nevertheless included at the end of this essay that are mindful of the current realities with respect to unpaid and precarious work.

Given these qualifications and parameters, the New Zealand material provides a relatively clear sense of periodisation, in fact dating back to 1840. In the first instances of the organised 
colonisation of New Zealand at least some of the migrants worked an eight-hour day. It is unclear how extensive this was, and certainly some workers worked longer hours or moved to longer hours during subsequent periods, particularly periods of local economic difficulty. Regardless, in seeking to attract migrants from Britain, New Zealand promoted itself as an eight-hour day destination. But by the late 1870 s through to the 1890 s, the period usually referred to as the "long depression," there is substantial evidence that many workers worked hours far in excess of eight hours a day. The growth of unions in the late 1880s appears to have produced some improvement. But more importantly, a reaction to publicity relating to poor working conditions led, from the mid-1890s, to the beginning of effective legislative assistance which aided workers to either consolidate reductions in, or start to reduce, hours of work and move toward an ultimate goal of a nationally applied eight-hour day. ${ }^{36}$

Providing numerous references to long hours worked in the 1870 s, J. D. Salmond's revised and respected thesis ${ }^{37}$ includes, for example, Wellington bootmakers being "asked to work 16 hours a day," Wellington seamen obtaining an agreement to work twelve hours out of 24 , and Christchurch stokers working 84 hours a week. ${ }^{38}$ The parliamentary debates in the 1880 s and 1890s are also a rich source of similar evidence. Railway engine drivers worked ten hours a day with claims that they worked twelve to fifteen hours a day. ${ }^{39}$ General engine drivers and bullock drivers worked ten to twelve hours a day. ${ }^{40}$ Workers for millers worked twelve-hour shifts. ${ }^{41}$ Domestic servants worked from 6 a.m. or 6.30 a.m. to 10 p.m. and grooms and menservants even longer. ${ }^{42}$ Hotel waiters had to be first up in the morning and were last to end their day. ${ }^{43}$ James Bradshaw, who repeatedly pressed for eight-hour day legislation, stated in 1886 that "at the present time the number of strikes occurring in this colony owing to the number of boys who are kept working at all hours of the day and night is very large: in fact, they are worked, in some factories, from nine to fifteen hours a day." ${ }^{44}$ In the process of arguing against a previous Eight Hours Bill in 1884, Downie Stewart, also an Otago parliamentarian, nonetheless accepted that "some employers would compel their workmen to work ten to fifteen hours a day." 45 Further evidence of long hours was gathered by the 1890 Sweating Commission. The publication of its report-which disclosed poor wages, long hours and poverty - contributed to the election of the Liberal Government in 1890 and provided impetus for its reformist agenda, which included a suite of labour matters. ${ }^{46}$

There are several indications that hours of work were improving by the 1890s. Although there was a general theme of unacceptable working conditions in the submissions to the Sweating Commission, there was also an indication that the growth in New Zealand unionisation in the late 1880s, which lasted until the catastrophic defeat of the main unions in the maritime strike in the late 1890, was helping reduce the hours of work in some areas. The Tailoresses Union said that it had "stopped entirely the taking of work home," that is, work done in addition to normal work in the factory. ${ }^{47}$ The Bakers' Society told the commission that "the bakers are now employed eight hours a day, and before the society was formed they worked in some cases sixteen hours a day for the same pay that they now get for eight hours." 48 The Bootmakers Union claimed that they were able to prevent workers performing work at home and were holding hours of work to eight hours for six days. ${ }^{49}$

The awards under the Industrial Conciliation Act 1894 began to impact the labour market from 1897 onwards. Some unions entrenched their traditional eight-hour days performed over six days a week or similar working weeks with more time worked on weekdays and less on Saturday. These included various building trades workers and coal miners. ${ }^{50}$ Others covered by early recommendations and decisions from the Arbitration Court that provided for 48 hours or less a week included tailoresses, linotypists, furniture trade workers, bootmakers, curriers 
and metal workers. ${ }^{51}$ Over time, the pool of workers covered by these hours of work provisions increased and the hours of work recorded in the awards generally fell. ${ }^{52}$

Legislation to directly control male hours of work was finally introduced at the commencement of the twentieth century. Throughout the $1880 \mathrm{~s}$ and the $1890 \mathrm{~s}$, such controls had been vigorously promoted by progressives and opposed by conservatives and the business community. Both promoters and resistors foresaw controls effecting reductions in the number of hours actually worked. In 1884, for example, the premier, Robert Stout, stated that the Eight Hours Bill would stop workers being "ground down by long hours of labour." 53 Others argued that the legislation would give workers scope for more leisure activity and enable them to more fully perform their parental functions. ${ }^{54}$ Opponents of the legislation threatened various devices to lower pay and create insecure work. They saw the reduction of hours of work resulting from the legislation as wasting investment, holding back the development of the colony and reducing its competitiveness with other colonies. ${ }^{55}$ Downie Stewart had changed his position on the eight-hour day by 1889 and now approved suitable legislation: if passed, "probably this colony will be ahead of all other countries in the world in seeing that the labouring classes are protected, and that no undue pressure is brought to bear on them." ${ }^{, 56}$ A progressive provision was finally passed in the Factories Act in 1901. Seddon, the premier, proclaimed that "at all events, we have here fixed the forty-eight hours a week, or eight hours a day, and in that I think we are in advance of any other Legislature, except as applied to mines." ${ }^{, 57}$ The opponents were resentful, one predicting that the Australian woollen mills, which worked longer hours, would take "our trade." 58

The evidence of the likely pattern of improvement from the 1890s is extended and reinforced with the publication in the New Zealand Official Year-Book from 1923 of a data series based on awards. The 1932 Year-Book shows a decline, following the Huberman and Minns sequence, of $5.9 \%$ in standard weekly hours from 1913 to 1929. Subsequent year-books show a decline in hours from 1929 to 1938 of about $11 \%$ and from 1938 to 1950 of about 3\%. From 1950 to 1960 there was no reduction in standard hours. The year-books began publishing average actual total weekly hours in 1958. The data indicate a decline in actual hours of $3.3 \%$ from 1960 to 1973, an increase of 2.9\% from 1973 to 1980, a decline of $1.2 \%$ from 1980 to 1990 , and a further marginal decline of $0.8 \%$ from 1990 to 2000 . The increase in average weekly hours for 1973 to 1980 does not extrapolate directly to a similar increase in annualised hours because of the increase in annual holidays during the decade. The increase of a week's leave by statute in 1974 and by way of related contractual adjustments for those previously receiving above the statutory minimum reduced annualised hours work by about $2.1 \% .^{59}$ It is noteworthy that the alignment of the series based on awards and actual hours for the period from 1957 to 1960 tends to support the usefulness of the award data.

The most notable feature of these data is the dramatic decrease in hours between 1929 and 1938. This needs some explanation. Intuitively, it might seem that the decrease reflected the extent of underemployment during the Great Depression. In fact, short time associated with the depressed economic activity was not reflected in the award data. The Industrial Conciliation and Arbitration Act was temporarily neutralised during the worst years of the economic crisis by the United and the United-Reform Governments, ${ }^{60}$ and the data remained almost static from 1930 to 1935 . The significant reduction of more than $10 \%$ occurred after 1935. This was the result of the return of the arbitration system to its previous functionality following the election of the First Labour Government and legislation setting 40 hours as the standard work week for all workers except those in the agriculture sector. ${ }^{61}$ An increasing number of New Zealand's 
industrial awards for office workers also began to include 38- and 37.5-hour weeks from 1937.62

The evidence is that progress was much slower after 1938. There may have been some decrease in weekly hours during the Second World War, associated with the increasing participation of women in the paid workforce. ${ }^{63}$ Furthermore, legislation was passed in 1944 to provide two weeks paid annual holiday. ${ }^{64}$ It is unclear how far this codified existing leave entitlements but it is likely to have decreased the annualised rate of working hours relative to weekly hours at least to some degree. There is little evidence of notable progress following the war, with three exceptions dating from the 1970s. ${ }^{65}$ As noted above, legislation in 1974 extended paid annual holidays to three weeks for the entire labour force, largely offsetting, in relation to annualised working hours, the increase in average weekly hours. A fourth week was added for 2007 which would have similarly reduced the annualised hours of work. ${ }^{66}$ There may have also been a brief period of industrial bargaining success that extended the 37.5-hour week to an increasing number of office workers during the first half of the 1970s. ${ }^{67}$

Even the relatively small falls in hours of work from 1980, and particularly from 1990 to 2000, might appear surprising given the contemporary narrative of increasing hours of work in New Zealand over the last nearly thirty years. ${ }^{68}$ Again, as above, this may reflect the weak capture in official surveys of an increasing number of unpaid hours of work.

Overall, the year-book data on actual hours of work show that hours of work reduced by only $3 \%$ from 1960 to 2000. A more detailed review of the data on an annual rather than decadal basis shows that the lowest average was recorded in 1978 at 36.4 hours and there was a return to a high of 39.4 hours in 1995, in fact higher than the average in 1957. The 1995 figure corresponds to the proximate impact of the Employment Contracts Act which deregulated the labour market and deunionised great swathes of the work force.

To return to Huberman and Minns and their argument that the period 1870 to 1913 was mimicked after 1950, the evidence is that this is not generally true of New Zealand. From 1840 to 1875 , it is possible that New Zealand had amongst the shortest hours of work anywhere. From 1875 to the 1890 s, circumstances almost certainly deteriorated. With equal certainty they substantially improved from the 1890s to the commencement of the First World War. By comparison, from 1950 to 2000 , progress appears to have been largely confined to two increases in holidays and a reduction in standard hours for some office workers and a small overall decrease in formal hours likely diminished or even reversed by increasing unpaid work.

The New Zealand research explains the first parts of this pattern to 1901 by reference to idealism, ideology, theory, labour power, economic circumstance and self-serving interest, and individual and small group agency. ${ }^{69}$ These are issues that relate to very particular changes in New Zealand. What, also, does the research, coupled with a consideration of the New Zealand experience during the twentieth century, say directly to the general causal factors that Huberman and Minns focus upon?

There is no available data set that shows the trend in wage inequality at the enterprise level in New Zealand. Given this, some reference to inequality indicated by concerns over poverty may still be of use. The first and most obvious period of colony-wide concern was the period of the long depression which prompted the Sweating Commission investigation in 1890. The shock of their report is considered to have been one of the catalysts for the emergence of the Liberal Government in 1891. Prominent in the work of the commission was its investigation into low 
wages throughout the colony. ${ }^{70}$ Similarly, the period of the Great Depression caused not only high unemployment but also the reduction of wages. ${ }^{71}$ More recently, inequality has reemerged as a significant public concern and political issue. Max Rashbrook notes that "New Zealand was historically one of the developed world's more equal societies. But following the unprecedented increase in income inequality between the mid-1980s and mid-1990s, we have fallen in the rankings." 72 There appears to be at least some correlation between these profoundly negative experiences and static and even increasing worktime.

Labour power in New Zealand in the nineteenth century, as elsewhere, was affected by generally low union density. ${ }^{73}$ There was rapid union growth from the late 1880 s which reflected an international trend of "new unionism," but it was only a fleeting experience that was crushed in the maritime strike in 1890. Otherwise, there is significant evidence of work by labour activists and their supporters to try and offset the disadvantage of poor density by obtaining legislative progress. This included proposing bills to restrict hours of work for women and children in the 1870s and to generally establish the eight-hour day in the 1880s and 1890s. All the Eight Hours Bills were strongly opposed by the Legislative Council, the upper house of the New Zealand Parliament, and failed to pass into law. Fundamentally, the conservatives in the council represented the interests of employers and argued against shorter hours on the basis of freedom of contract, the need for the market to operate unhindered, unaffordability, the challenges of international competition, and the dire consequences of not meeting these challenges. They also warned workers of serious consequences of reduced income and casualisation. The ability of this opposition to obstruct weakened over time following the election of the Liberals. As above, this election has already been attributed to concern over poverty. Other attributions have been the industrial defeat of the unions in the maritime strike (underscoring the importance of political activism) and an extension of the franchise. $^{74}$

The Liberal Government's statutes that particularly advanced the cause of shorter hours were the Industrial Conciliation and Arbitration Act 1894 and the Factories Act 1901. The first involved the development of the quasi-legislative protection of industrial awards (the result of government supported collective bargaining between registered unions and employers). The second was the first of a series of parliamentary measures that included the regulation of standard hours for factories, mines, shops and offices. The statutes were the cornerstones of progress and protection for hours of work that culminated in the establishment of the 40-hour week benchmark in $1936 .{ }^{75}$ It is not apparent that unions or workers made significant progress in reducing hours outside these structures.

The Labour Government was defeated in 1949 and there is little evidence of progress under the conservative National Party that followed and held power almost continuously until 1972. The Labour Government from 1972 to 1975 increased paid annual holidays to three weeks in 1974. The term may also have been associated with further successful industrial bargaining for the reduction of weekly hours to 37.5 for some office workers. Returning to power in 1975 , National reduced the effectiveness of the statutory eight-hour day in 1981. Defeated at the polls in 1984, it was followed by a Labour Government that began a substantial deregulation of the economy. This was a prelude to the wholesale dismantling of the industrial awards system executed under the Employment Contracts Act which was passed by National shortly after it again returned to power in 1990. Industrial labour was politically marginalised and suffered dramatic losses in union membership. A weak recovery followed after 1999 with the election of a Labour-led government, which also provided a fourth paid week of annual holidays. But weekly hours increased for some as well. ${ }^{76}$ 
Progress towards shorter hours is clearly linked to electoral outcomes and political power in New Zealand. When conservatives and employers have held sway, progress has been nonexistent, excepting for the continued operation of the industrial award system initiated by the Liberals. A consistently important part of the rationale for opposing progress has been risk to employers, business, and to the economy in generally. Employer groups cited in the Employment Contracts Act debate, for example, said they believed the new employment law would "lead to a more productive and competitive economy." The National Government stressed a context of "falling productivity" and an economy "at the very bottom of the OECD countries." $" 77$ The demand was for workers to work harder to enable New Zealand to achieve economic success in the intensely competitive international marketplace. The determination was to break labour power and influence to enable this to happen. In contrast, the election of left or left-leaning governments, one expression of labour power, resulted in periods of progress in the reduction of hours.

Fortunately, data on work ethic comparable to that used by Huberman and Minns are available from the New Zealand Census. This shows that in 1871 nearly $80 \%$ of the population indicated a Protestant denomination. It also appears from literacy figures that probably about half of the population from 5 to 15 years of age attended school. The Protestant percentage was almost unchanged in 1911. The literacy data for school age population for the same year regrettably excludes Maori and Chinese but for the population counted it appears that primary school attendance may have become almost universal. ${ }^{78}$ Based on the Huberman and Minns framework, the expectation would be that New Zealand workers were inclined to work even harder and longer than their counterparts in other New World countries. But the evidence suggests quite the contrary.

New Zealand has a number of claims in relation to progressive working hours. Clearly the eight-hour day was initially established to some degree in its Wakefield settlements in the 1840s. ${ }^{79}$ Worldwide, these settlements were well ahead of their time. Seddon, the prime minister, claimed the Factories Act of 1901 also put New Zealand globally at the head of hours of work legislation. ${ }^{80}$ This was similarly the case in 1936 with the legislation that set the standard 40-hour week. ${ }^{81}$

Various sources indicate that one of the reasons British colonists came to New Zealand was to work less. ${ }^{82}$ In terms of the very earliest evidence of the eight-hour day in New Zealand, a Mr Hicks wrote to his brother in 1840 that he did "not want to return to England to work hard. We work eight hours a day for our two pounds per week . . . if you were to know how things were going on you would stop in England but a very little while; for this [Wellington] is an excellent place." 83 An 1843 petition from the workers in Nelson, protesting deteriorating conditions, plead that "no man is so happy as the working man for when his day's work [is done], he comes home to his family and by his own fireside he enjoys the fruits of Industry we do not want large fortunes of Extraordinary Incomes but to live Comfortably and decently." "In the mid-1870s, the New Zealand government sought to entice more migrants by referring to the general observance of the eight-hour day. ${ }^{85}$ In a parliamentary debate in 1887 , tension was high as members disputed who should be given credit for the initial establishment of the eight-hour day in New Zealand. ${ }^{86}$ In 1936, Savage, the prime minister, and with Seddon one of New Zealand's most popular and beloved leaders, said in reference to the establishment of the 40hour week that "he himself had never worked for the love of work, and he had yet to meet the man who did." Australian and Roman Catholic, he nevertheless spoke of and for New Zealand's overwhelmingly Protestant workers. He added that "as long as the machine 
continued to increase production, the only rational thing was for men and women to work shorter hours." $" 87$ The tenor of media commentary on the modern return of longer hours is generally critical. ${ }^{88}$

Fundamentally, longer hours and constraints on progressing to shorter hours in New Zealand have come not from the inclination of workers but from employers, from their economic selfinterest and insistence that economic disadvantage, likely to be disastrous, will be incurred by the whole community if workers remove their shoulder from the wheel.

It would have been better if Huberman and Minns had confined themselves to North America and even just to the United States instead of broadening their interest to the New World and seeking to include Australia in their generalisations. Even so, there would still have been difficulties. The suggestion of continuity leaping across the divide of the world wars and the Great Depression is contrary to the general argument presented in Hunnicutt's detailed and mostly compelling study of American worktime. Hunnicutt shows the importance of organised labour and other voices working to reduce worktime through the late nineteenth century and to up the New Deal only to be finally stopped by a major change in policy by Roosevelt as he moved from a proposed 30-hour week to economic expansion driven by the "gospel of consumption." $" 89$ There is also no accounting for the almost certainly malign impact of the policies of Reagan from the 1980s on US workers' wages and conditions. ${ }^{90}$

There is no dispute here that the exercise of labour power was a force for the reduction of working hours. And the optics are that labour has been more successful in the exercise of this power in Europe than in the United States. The positive representation of inequality by Huberman and Minns is more controversial. In their view, the "marginal worker" comes to the United States for longer hours of work; the employer is meeting the demand; the employers supply a ladder of opportunity for workers to earn more. Huberman and Minns use the contemporary language of employers and business. ${ }^{91}$ Lonnie Golden, in "A Brief History of Long Work Time and Contemporary Sources of Overwork," provides at least five possible reasons for the performance of longer hours: the adequacy of current real wage rates; the potential for higher wages; the "relative status" conferred upon individuals for hours of labour effort; "intrinsic rewards, process benefits, or amenities acquired through work"; and "hours demanded by employers reflecting structural constraints." Golden makes explicit that "employers and their established conditions of work have influenced the course of long run trends [in] labor supply and work time structures." 92 It is also not at all clear that the migrants came to New World to work longer and did work longer because they were Protestant or that their families invested in more schooling. To render a significant part of the causal argument from Huberman and Minns plausible, the New World workers had to work longer hours when in actual fact for most of the time they did not.

Huberman and Minns's essay culminates in the casting of doubt on the general efficacy of European policies aimed at reducing hours of work. The suggestion is that there is something in the natures of either the New World worker or New World societies that makes them more industrious, more dynamic, and that European policies will not work and should not be imposed on these workers and societies that are in tune with the virtue of productive work. The policy changes of Roosevelt and Reagan which redirected and forced change indicate that the US government can influence worktime, whether to hinder or promote, and that there is no such American immunity or need to be protected from the Europeans. The same applies with reference to New Zealand, where politics and government policy have been decisive in 
influencing patterns of progress and regression in relation to a general desire of workers to work less hours.

As a final comment, the question of policy should not be narrowly framed. Consideration of the length of worktime is a subset of the need to address the future of work generally. This much larger matter includes vital issues. One is modernising the management of work and rethinking control. Also required is an understanding of how rights to work should be aligned with the equitable distribution and socialisation of wealth and income in a progressive society in which necessary work is increasingly limited. The great need is to develop more comprehensive policy, not to resist even limited initiatives and innovation.

\footnotetext{
${ }^{1}$ As usual, I am much indebted to Jen Wilson, Rosemary Mercer and Marcus Henning for their kindness and assistance.

${ }^{2}$ M. Huberman and C. Minns, "The Times they are not Changin': Days and Hours of Work in Old and New Worlds, 1870-2000," Explorations in Economic History 44 (2007): 538-67.

${ }^{3}$ R. Markey, "The Australian Place in Comparative Labour History," Labour History 100 (2011) 175.

${ }^{4}$ Huberman and Minns, "The Times they are not Changin'," 539n. For a more detailed criticism of the methodology of Huberman and Minns see J. Henning, "Regulating for Shorter Hours: a Critique of Huberman and Minns" (2018), Jon Henning Papers, ARC-0856, Hocken Library, Dunedin.

${ }^{5}$ Huberman and Minns, "The Times they are not Changin'," 563.

${ }^{6}$ Huberman and Minns, "The Times they are not Changin'," 548.

${ }^{7}$ Huberman and Minns, "The Times they are not Changin'," 548.

${ }^{8}$ Huberman and Minns, "The Times they are not Changin'," 548.

${ }^{9}$ Huberman and Minns, "The Times they are not Changin'," 545, 560.

${ }^{10}$ Huberman and Minns, "The Times they are not Changin'," 545, 550.

${ }^{11}$ Huberman and Minns, "The Times they are not Changin'," 541.

${ }^{12}$ Huberman and Minns, "The Times they are not Changin'," 539, 540.

${ }^{13}$ Huberman and Minns, "The Times they are not Changin'," 539.

${ }^{14}$ Huberman and Minns, "The Times they are not Changin'," 556, 558.

${ }^{15}$ Huberman and Minns, "The Times they are not Changin'," 539.

${ }^{16}$ Huberman and Minns, "The Times they are not Changin'," 558.

${ }^{17}$ Huberman and Minns, "The Times they are not Changin'," 539-40.

${ }^{18}$ Huberman and Minns, "The Times they are not Changin'," 544.

${ }^{19}$ Huberman and Minns, "The Times they are not Changin'," 539, 545.

${ }^{20}$ Huberman and Minns, "The Times they are not Changin'," 544.

${ }^{21}$ Constraints may relate not to federalism itself but to other content; in particular, constitutions.

${ }^{22}$ Huberman and Minns, "The Times they are not Changin'," 544.

${ }^{23}$ Huberman and Minns, "The Times they are not Changin'," 545.

${ }^{24}$ Huberman and Minns, "The Times they are not Changin'," 546.

${ }^{25}$ Huberman and Minns, "The Times they are not Changin'," 545-47.

${ }^{26}$ Huberman and Minns, "The Times they are not Changin'," 560.

${ }^{27}$ Huberman and Minns, "The Times they are not Changin'," 560, 562.

${ }^{28}$ Huberman and Minns, "The Times they are not Changin'," 543.

${ }^{29}$ Huberman and Minns, "The Times they are not Changin'," 552, 559-60.

${ }^{30}$ Huberman and Minns, "The Times they are not Changin'," 559.

${ }^{31}$ Huberman and Minns, "The Times they are not Changin'," 540.

${ }^{32}$ J. Henning, "Prosaic Realities of the Work Time Dream," Journal of New Zealand Studies NS25

(2017): 57-71; E. Rasmussen and J. Burgess, "Too Much of a Good Thing: Longer Working Hours in Australia and New Zealand" (paper presented at the 22nd AIRAANZ conference, Auckland University, 7-9 February, 2007); H. Johnson, “Out of Control,” Scoop 55 (28 May 2015).

${ }^{33}$ Henning, "Prosaic Realities."
} 
${ }^{34}$ The New Zealand data discussed below are from the New Zealand Official Year-Book (Wellington, 1923-2002) unless stated otherwise. First quarter or half actual hours figures are used where published.

${ }^{35}$ Unpaid time has long been a feature of the work of some salaried workers, such as public servants. There are related references as early as the 1880 s to parliamentary staff and other clerks: see New Zealand Parliamentary Debates (Hansard) [hereafter NZPD] 41 (1882), 172, 175; 79 (1893), 118; 91 (1895), 444. In relation to the more recent trend, see Rasmussen and Burgess, "Too Much of a Good Thing," and Johnson, "Out of Control."

${ }^{36}$ Henning, "Prosaic Realities."

${ }^{37}$ E. Olssen, Building the New World (Auckland University Press, 1995), 289.

${ }^{38}$ J. D. Salmond, "The History of the New Zealand Labour Movement" (PhD thesis, New Zealand, 1923-24, revised 1928, Hocken Library), 87, 88, 153.

${ }^{39}$ NZPD 41 (1882), 171, 177-78; 43 (1882), 65.

${ }^{40}$ NZPD 64 (1889), 222.

${ }^{41}$ NZPD 96 (1896), 107.

${ }^{42}$ NZPD 42 (1882), 381.

${ }^{43}$ NZPD 42 (1882): 381

${ }^{44}$ NZPD 54 (1886): 340

${ }^{45}$ NZPD 49 (1884): 24.

${ }^{46}$ Henning, "Prosaic Realities," 65-66.

${ }^{47}$ Appendix to the Journals of the House of Representatives [AJHR] H.-5 (1890), 5.

${ }^{48}$ AJHR H.-5 (1890), 33-34.

${ }^{49}$ AJHR H.-5 (1890), 15.

${ }^{50}$ Department of Labour, Awards 1 (1901), 9, 17, 41, 350, 410, 444.

${ }^{51}$ Department of Labour, Awards 1 (1901), 24-25, 28, 49, 325, 356, 372, 384, 399, 424.

${ }^{52}$ Department of Labour, Awards, passim. Also see for example NZPD 116 (1901), 304.

${ }^{53}$ NZPD 49 (1884), 22.

${ }^{54}$ NZPD 79 (1893), 121.

${ }^{55}$ NZPD 42 (1882), 381; 57 (1887), 347-48, 377; 73 (1891), 319-20.

${ }^{56}$ NZPD 64 (1889), 220.

${ }^{57}$ NZPD 119 (1901), 388.

${ }^{58}$ NZPD 119 (1901), 1010.

${ }^{59}$ Annual Holidays Amendment Act 1974, S.3.

${ }^{60}$ J. Holt, Compulsory Arbitration in New Zealand (Auckland University Press, 1986), 186-89.

${ }^{61}$ Industrial Conciliation and Arbitration Amendment Act 1936, S.20.

${ }^{62}$ The earliest example of workers working less than a 40-hour week appears to be some central government office workers on standard 38-hour weeks before the First World War, perhaps dating from the time of the Liberals (Public Service Journal 1, no. 8 [August 1914], 33). The first workers under an award (public servants were excluded from the coverage of the Industrial Conciliation and Arbitration Act) appear to have been Auckland Gas Company office workers (Public Service Journal 22 [1921], 1311). For examples following the Industrial Conciliation and Arbitration Amendment Act 1936, see local council office workers employed by Auckland City Council (Public Service Journal 37 [1937], 1776) and Nelson local bodies (Public Service Journal 38 [1938], 3892).

${ }^{63}$ AJHR H.-14 (1944), 1, 3-4.

${ }^{64}$ Annual Holidays Act 1944, S.3.

${ }^{65}$ Department of Statistics, Prices, Wages, Labour (Wellington, 1967), 42.

${ }^{66}$ Holidays Act 2003, S.1.

${ }^{67}$ For example, Department of Labour, Awards: Otago Hospital Board clerks (73 [1973], 4799); New

Zealand Shipping Company clerks (73 [1973], 3113); and Rodney County Council workers (75 [1975], 3937).

${ }^{68}$ Rasmussen and Burgess, "Too Much of a Good Thing," and Johnson, "Out of Control."

${ }^{69}$ Henning, "Prosaic Realities."

${ }^{70}$ Henning, "Prosaic Realities."

${ }^{71}$ M. King, The Penguin History of New Zealand (Auckland: Penguin, 2012), 346.

Journal of New Zealand Studies NS28 (2019), 69-83 https://doi.org/10.26686/jnzs.v0iNS28.5421 
${ }^{72}$ M. Rashbrooke (ed), Inequality: A New Zealand Crisis (Wellington: Bridget Williams Books, 2013), 23, 28.

${ }^{73}$ The Huberman and Minns model is principally concerned with change after 1870 and with labour power expressed by unions and the electoral vote. It is noteworthy, however, that there is evidence of the expression of labour power in a general market sense at the outset of the organised colonisation of New Zealand. In particular, the original observance of the eight-hour day in the early Wakefield settlements related to a shortage of labour, especially skilled labour (Henning, "Prosaic Realities." 59). Conversely, the long depression may be associated with a weak labour market and thus long hours. Research indicates the contrary effect in the Great Depression with accounts of underemployment (K. Rankin, "Unemployment in New Zealand at the Peak of the Great Depression" [paper presented at the Conference of the Economic History Association of Australia and New Zealand, 1994]).

${ }^{74}$ Henning, "Prosaic Realities."

${ }^{75}$ Henning, "Prosaic Realities"; Johnson, "Out of Control."

${ }^{76}$ Supplementing citations already provided, see G. Anderson, ed., Transforming Workplace Relations in New Zealand 1976-2016, with A. Geare, E. Rasmussen and M. Wilson (Wellington: Victoria University Press, 2017) 13 and passim.

${ }^{77}$ NZPD 515 (1991), 1648-49.

${ }^{78}$ Census of New Zealand 1871 (Wellington: Government Printer, 1872), tables 16, 20; Census of New Zealand 1911 (Wellington: Government Printer, 1912), 99, 271.

${ }^{79}$ Henning, "Prosaic Realities," 57

${ }^{80}$ NZPD 119 (1901), 388.

${ }^{81}$ NZPD 246 (1936), 519.

${ }^{82}$ Henning, "Prosaic Realities," 57.

${ }^{83}$ New Zealand Journal, 15 January 1841, as cited in Jon Henning, "A Rejection of Bondage" (MA Thesis, University of Otago, 2004), 230n.

${ }^{84}$ Nelson Examiner, 21 January 1843, as cited in Henning “A Rejection of Bondage," 193-94.

${ }^{85}$ Henning, "Prosaic Realities", 60.

${ }^{86}$ NZPD 64 (1889), 216-29.

${ }^{87}$ NZPD 246 (1936), 405. Undoubtedly, against this general observation, there have always been some workers who, uninfluenced by their employer, want to work longer.

${ }^{88}$ Johnson, "Out of Control."

${ }^{89}$ Also included in Hunnicutt's general argument is an observation that American unionists in the nineteenth century sought, in part, to reduce hours and thus labour supply in order to increase wages (B. Hunnicutt, Work Without End [Philadelphia: Temple, 1988], 9-10).

${ }^{90}$ J. Stiglitz, The Price of Inequality (London: Penguin, 2013), xxxii.

${ }^{91}$ Huberman and Minns state at one point in their paper that "the assumption that firms are indifferent to the type of schedule offered to workers does not mesh with the historical record in which employers of the world signalled different preferences" (Huberman and Minns, "The Times they are not Changin'," 550). Even here, the language is still one of enablement and without any sense of asymmetrical power and the dominance of employers over workers. For a view more reflective of mainstream thinking prior to the onslaught of neoliberalism, see O. Kahn-Freund, Labour and the Law (London: Stevens and Sons, 1972), chapter 1.

${ }^{92}$ L. Golden, "A Brief History of Long Work Time and Contemporary Sources of Overwork," Journal of Business Ethics 84 (2009), 217. 